\title{
TRADISI DOA PADANG DI KABUPATEN KUANTAN SINGINGI Kajian Antropologis
}

\author{
Petra Yuhendri \\ Jurusan Studi Agama-Agama, Fakultas Ushuluddin, UIN SUSKA Riau \\ Email: petra.yuhendri@uin-suska.ac.id
}

\begin{abstract}
Abstrak
Tradisi doa padang merupakan usaha yang dilakukan para petani memohon dan meminta kepada sang pencipta agar diberikan keselamatan tahun berupa tanah yang subur, terbindar dari bencana alam, hama penyakit dan dapat memberikan hasil panen padi yang berlimpah pada masyrakat desa jaya kopah kecamatan kuantan tengah kabupaten kuantan singingi. Disebut tradisi doa padang karena prosesi doa dilakukan ditanah lapang yang masyarakat menyebutnya dengan padang. Tulisan ini berupaya menggali lebih dalam tentang proses pelaksanaan tradisi doa padang dan urgensi doa padang bagi masyarakat desa Jaya Kopah. Sehingga tradisi ini masih terus dilaksanakan dan dapat bertahan hingga sekarang. Tradisi tradisi doa padang merupakan wujud pewarisan tradisi nenek moyang dengan adanya dorongan dari para ninik mamak bertujuan berdoa kepada Allab SWT agar diberikan keselamatan tahun pada persawahan atau padi para petani seperti tanah menjadi subur, terhindar dari bencana alam, penyakit, hama padi dan mendapatkan hasil panen yang belimpah. Selain itu, berarti masyarakat masib menjaga dan mempertahankan tradisi nenek moyang dan melengkapi kegiatan tahunan mereka. Temuan penelitian ini selanjutnya tentang solidaritas masyarakat yang dapat dilihat dari antusias masyarakat dalam bekerja sama dalam segala hal demi kelancaraan pelaksanaan doa padang seperti gotong royong, memotong dan memasak sapi, membuat jambar godang serta mempererat bubungan tali silaturrahmi.
\end{abstract}

Kata Kunci: tradisi, doa padang, hasil panen

Abstract:

The Padang prayer tradition is an effort made by farmers asking and asking the creator so that safety is given in the form of fertile soil, protected from natural disasters, pests and diseases, and the year can provide abundant rice harvests to the people of Jaya Kopah Village, Central Kuantan District, Kuantan Regency. singi. It is called the Padang prayer tradition because the prayer procession is carried out in a field called the Padang. This writing takes a deeper note of the process of the Padang prayer tradition and the urgency of the Padang prayer for the people of Jaya Kopah village. So that this tradition is still carried out and can survive until now. The Padang prayer tradition is a form of inheritance of ancestral traditions with the encouragement of the ninik mamak aimed at praying to Allah SWT so that the safety of the year is given to the rice fields of the farmers such as land into cities, avoiding natural disasters, diseases, rice pests and getting good harvests. abundant. In addition, it means that the community still maintains and maintains the traditions of their ancestors and completes their annual activities. The findings of this study are further about community solidarity which can be seen from the enthusiasm of the community in being the same in all respects for the smooth implementation of field prayers such as mutual cooperation, making jambar godang, and strengthening the relationship of friendship.

Keywords: tradition, The Padang Prayer, yield

\section{PENDAHULUAN}

Tradisi masih dipahami oleh semua orang sebagai bagian dari kebiasaan yang turun temurun yang sudah sejak lama dan menjadi bagian dari kehidupan suatu masyarakat. Apakah tradisi tersebut berupa kepercayaan kepada kekuatan gaib, adat istiadat atau berupa tradisi lainnya yang berkaitan dengan pola tingkah laku masyarakat

NUSANTARA; Journal for Southeast Asian Islamic Studies

Vol. 16, No. 2, Desember 2020 


\section{NUSANTARA; Journal for Southeast Asian Islamic Studies}

Vol. 16, No. 2, Desember 2020

tersebut. ${ }^{1}$ Realitas masyarakat yang beragam suku bangsa yang berbeda, serta agama yang berbau mitos merupakan dasar dalam kehidupan sosial. Sejak dahulu masyarakat percaya terhadap adanya kekuatan gaib yang mengatur alam ini. Ada yang mendatangkan keuntungan ada pula yang merugikan.

Berdasarkan kepercayaan tersebut manusia senantiasa akan berupaya untuk selalu menjalin hubungan yang baik atau melembutkan hati pemilik kekuatan gaib tersebut baik itu dari sang pencipta maupun yang lainnya dengan mengadakan upacara ritual, doa, ziarah, sesaji, khaul dan lain sebagainya.

Maka dari peristiwa tersebut timbullah ' $U r f$ (kebiasaan) ditengah-tengah masyarakat yang kemudian tersebar menjadi adat dan budaya atau kebiasaan tetangga lingkungan dan semacamnya menjadi model kehidupan sesuai dengan keadaan lingkungannya. ${ }^{2}$

Beraneka ragam tradisi yang dilaksanakan dan dilestarikan oleh masyarakat mempunyai tata cara pelaksanaan, bentuk, makna dan tujuan yang berbeda-beda antara masyarakat yang satu dengan masyarakat yang lain. Hal ini tentunya disebabkan oleh beberapa faktor seperti kondisi lingkungan, adat serta tradisi yang diwariskan. ${ }^{3}$ Gejala semacam ini dianggap normal. Karena pada dasarnya tradisi merupakan informasi yang disampaikan dari generasi ke generasi yang terus berjalan baik secara tertulis maupun lisan yang terkadang akan berubah sesuai dengan perkembangan zaman dan keadaaan masyarakat yang membuatnya dapat bertahan.

Kabupaten Kuantan Singingi (Kuansing) merupakan salah satu daerah kabupaten yang secara administratif termasuk dalam Provinsi Riau. ${ }^{4}$ Mata pencaharian mayoritas penduduknya adalah di sektor pertanian. Memiliki lahan sawah ratusan hektar dan lahan kering yang dapat digunakan untuk lahan pertanian pun tidak sedikit. Melihat begitu banyak harapan masyarakat yang bertumpu pada sektor pertanian yang sudah digeluti sejak zaman nenek moyang dulu maka

1 UU. Hamidy, Nilai-Nilai Suatu Kajian Awal (Pekanbaru: UI Perss, 1993), hlm. 45

2 Syaikh Mahmud Syaltut, Fatwa-Fatwa Penting Syaikh Shaltut, (Dalam Hal Aqidah Perkara Gaib dan Bid'ah), (Jakarta: Darus Sunnah Press, 2006), hlm. 121 besar pula apresiasi dan antusias masyarakat dalam penyambutan serta pelaksanaan kegiatan ini. Salah satunya mengadakan ritual atau upacara tertentu sebelum memulai masa bercocok tanam disawah. Tradisi yang masih eksis dan masih tetap bertahan sampai saat ini adalah tradisi doa padang yaitu suatu tradisi penyambutan musim tanam padi yang dilakukan para petani, perangkat adat dan seluruh masyarakat sebelum menanam padi di sawah.

Tradisi doa padang dapat dikatakan sebagai sebuah peristiwa sosial yang telah menjadi wadah bagi masyarakat untuk memohon kepada sang pencipta agar diberikan keselamatan, kesuburan dan kelancaran dalam bercocok tanam hingga mendapat hasil panen yang berlimpah. Selain itu masyarakat berpendapat tradisi doa padang merupakan warisan turun temurun yang harus dilestarikan.

Hakikat lain dari pelaksanaan doa padang ini merupakan suatu momentum bagi penghulu adat dan para ninik mamak untuk menyepakati waktu yang tepat untuk memulai turun ke sawah secara serentak. Didalamnya mengandung konsep menghubungkan tali silaturrahmi antara mamak dan kemenakan serta menjaga amanah leluhur bahwa adanya kekuatan alam yang harus didukung dan dipertahankan untuk manjaga dan terhindar dari marabahaya. Diantaranya menghindari sawah dari wabah penyakit, gangguan hewan ternak dan hewan liar, musibah hingga bencana alam.

Di Kenegerian Kopah khususnya Desa Jaya Kopah, tradisi doa padang ini menjadi rutinitas tahunan upacara tradisional yang terus dijaga dan dipertahankan sebagai wujud syukur, permohonan dan penghormatan kepada sang pencipta yang telah memberikan rezeki dan segala kemudahan bagi masyarakat dalam kegiatan bercocok tanam serta terjaganya alam yang menjadi media dan pengharapan masyarakat.

Cara pelaksanaannya pun tergolong unik dan menarik. Masyarakat berbondong-bondong menuju dan berkumpul di tanah lapang sambil menikmati rarak calempong yang 6 dan gendang yang diiringi kalimat-kaliamt pujian kepada sang

3 Mukti Ali, Alam Pikiran Modern di Indonesia (Yogyakarta: Yayasan nida. 1969), hlm. 7

${ }^{4}$ Silawati dan Aslati, "Menguak Nilai-Nilai Magis pada Tradisi Pacu Jalur di Kabupaten Kuantang Singingi”, No 2, Tahun, hlm. 238 
pencipta dalam bahasa daerahnya mereka sebut dengan Dikiar. Berbagai rentetan acara akan dilaksanakan yang membahas seputar persawahan. Kemudian akan ditutup dengan pengadaan zikir bersama dan doa saropal onam (shalawatan). Agenda lainnya adalah makan bersama. Para petani akan menyiapkan lauk pauk dari rumah mereka masingmasing yang disajikan dalam sebuah Jambar atau Dulang. Didalamnya berisi lauk pauk serta makanan khas kuansing seperti lidah kambing, piniaram, godok, lopek dan lainnya. Selain itu, masyarakat juga akan membuat Jambar Godang (keranda besar) diisi dan digantungkan berbagai macam makanan tradisional yang dihias sedemikian dalam jumlah yang banyak. ${ }^{5}$

Inilah drama musiman masyarakat Desa Jaya Kopah sebagai aktivitas bermasyarakat dan meneruskan tradisi nenek moyang mereka. Dengan melihat fenomena tersebut merupakan hal yang menarik untuk diteliti untuk dapat mengetahui lebih dalam bagaimana pelaksanaan doa padang tersebut serta seberapa pentingnya doa padang itu sendiri bagi masyarakat khususnya para petani Desa Jaya Kopah.

\section{Sejarah Doa Padang}

Bercocok tanam merupakan kegiatan masyarakat desa jaya kopah sejak dahulu. Membuka lahan kosong dan memanfaatkannya untuk memenuhi kebutuhan sehari-hari. Tanah yang sudah lama terbengkalai atau tidak digunakan yang sudah ditumbuhi tanaman liar dan hewan atau hama penyakit akan kembali digarap dan diolah dengan baik sehingga dapat digunakan kembali. Seperti membuka lahan untuk menanam padi yang menjadi makanan pokok masyarakat dari zaman nenek moyong hingga sekarang ditambah luasnya daerah yang dapat dijadikan sebagai lahan bercocok tanam juga perlu untuk diperhatikan. Dengan melihat kondisi demikian maka besar pula apresiasi masyarakat dalam melakukan kegiatan ini seperti melakukan syukuran, doa bersama dan kegiatan lain yang dapat menunjang kelancarannya.

\footnotetext{
${ }^{5}$ Buyung, Datuk Suku Melayu, wawancara tanggal 20 Desember 2020

${ }^{6}$ Matnur, Kepala Desa Jaya, wawancara tanggal 01 Desember 2020
}

Sumber rezeki berasal dari yang maha kuasa baik yang datang dari langit maupun yang tumbuh dari tanah. Kita sebagai manusia hanya dapat meminta dan bersyukur terhadap apa yang ditimpakan kepada kita umat manusia. Datangnya rezeki dari langit berupa hujan yang tidak menentu akan menyirami tanaman dan menyuburkan tanah. Tanah yang bagus dapat ditanami dengan berbagai macam tanaman seperti padi, jagung, kelapa, sayur-sayuran dan lain sebagainya yang dapat memenuhi kebutuhan manusia. ${ }^{6}$

Oleh sebab itu, tradisi doa padang ini akan terus dilakukan dan dijaga mengingat besarnya pengharapan masyarakat terhadap tanaman padi bagi kehidupan. Selain itu tradisi ini merupakan warisan yang turun temurun dilakukan oleh generasi ke generasi masyarakat desa jayakopah atau masyarakat kenegerian kopah secara umumnya.

Dengan demikian pelaksanaan tradisi doa padang semata-mata memohon kepada Allah SWT jangan sampai segala sesuatu yang dapat merusak persawahan datang melanda. Baik yang berasal dari dalam tanah maupun yang turun dari langit dan alam sekitar.

Adapun untuk pelaksanaannya doa padang dilakukan di tampang yaitu tanah lapang yang terletak berada ditengah-tengah sawah masyarakat. Konon katanya tempat ini juga diyakini mempunyai kemujuran tersendiri dan dianggap cocok untuk melaksanakan doa padang karena dahulu ketika ada inisiatif lain pemindahan tempat seperti di rumah gadang (rumah adat) yang terjadi adalah kegagalan panen dan lain sebagainya. Oleh sebab itu, tradisi ini dinamakan dengan doa padang karena pelaksanaannya dilakukan di padang (tanah lapang) yang masyarakat menyebutnya dengan nama tampang.

\section{Persiapan Doa Padang}

Pertama, Rapat. Pada persiapan doa padang dimulai dengan rapat bersama. Rapat dihadiri oleh para tetua suku se-Kenegerian Kopah atau para datuk suku yang disebut ninik mamak. ${ }^{7}$

\footnotetext{
${ }^{7}$ Ninik mamak adalah pimpinan suku yang dipilih melalai musyawarah anggota keluarga laki-laki. Ninik mamak ini berperan menyelesaikan berbagai macam permasalahan dalam sebuah suku maupun antar suku karena itu orang yang
} 


\section{NUSANTARA; Journal for Southeast Asian Islamic Studies}

Vol. 16, No. 2, Desember 2020

Selain itu, rapat juga mengikut sertakan para alim ulama yang berada di lingkungan kenegerian Kopah hal ini bertujuan agar pelaksanaan adat tradisi tetap berpegang teguh dan berpatokan pada dasar agama. Dalam artian bahwa masyarakat tidak akan memisahkan antara adat dan agama yang diyakini oleh masyarakat agar tidak terjadi kesalahpahaman dalam pelaksanaannya. Rapat diadakan di rumah gadang (rumah adat Kenegerian Kopah). Dalam rapat tersebut akan diadakan perundingan atau musyawarah mengenai acara tradisi doa padang, mencari titik temu untuk mencapai kesepakatan bersama. ${ }^{8}$

Banyak hal yang dibahas dalam pertemuan tersebut seperti penentuan waktu akan dilaksanakannya tradisi doa padang dan dimulainya penanaman benih padi serta menentukan desa yang akan membawa jambar godang dan lain sebagainya. Rapat biasanya akan dihadiri oleh para datuk penghulu suku, ulama dan para pejabat desa.

Rapat rencana persiapan doa padang ini berguna untuk kegiatan yang lebih terarah dan dapat dipertanggung jawabkan serta saling yakin meyakinkan setiap ninik mamak dan masingmasing para perangkatnya (se-suku). ${ }^{9}$

Agusman K menambahkan, dalam pelaksanaannya tentu perlu persiapan yang matang. Mengingat acara ini melibatkan orang banyak (masyarakat desa jaya umumnya masyarakat kenegerian kopah) bukan sekedar kepentingan ninik mamak saja melainkan juga untuk mempertimbangkan kondisi alam dan hasil panen yang akan di dapatkan nantinya. Dengan adanya acara seperti ini tentu kegiatan-kegiatan yang akan dilaksanakan akan berjalan dengan khidmat tanpa ada pertentangan atau hal-hal yang tidak dinginkan nantinya ketika melaksanakan kegiatan bercocok tanam hingga masa panen. ${ }^{10}$

Kedua, Waktu. Kegiatan doa padang merupakan agenda rutin setiap tahunnya. Meskipun demikian penentuan waktu pelaksanaan akan terus dilakukan kerena bisa saja akan ada

terpilih menjadi nink mamak diharapkan memiliki pengetahuan mendalam tentang adat istiadat. Jika terjadi konflik atau hal-hal yang berhubungan dengan tradisi maka masing-masing ninik mamak akan bertemu dan melakukan perundingan salah satunya pelaksanaan tradisi doa padang.

8 Agusman K, Tungganai, wawancara tanggal 30 Agustus 2020 perubahan atau perbaikan. Hal ini bertujuan untuk mengikat kesepakatan pelaksanaan doa padang antara ninik mamak dan para bawahannya sangat mempertimbangkan kondisi alam dan sejarah nenek moyang terdahulu atau tahun sebelumnya. Ini bertujuan agar tidak terjadi hal-hal yang tidak diinginkan seperti musibah banjir, gangguan hama, padi tidak tumbuh dan lain sebagainya.

Perlu digaris bawahi bahwa pelaksanaan doa padang hanya dilakukan sekali dalam setahun. Jika terjadi suatu musibah seperti banjir, kekeringan dan menyebabkan gagal panen maka inisiatif yang diambil oleh para ninik mamak dan masyarakat adalah kembali mengatur atau mencari waktu yang tepat untuk kembali bercocok tanam tanpa harus melakukan doa padang untuk kedua kalinya.

Ketiga, Tempat. Tempat yang dimaksud merupakan tempat dimana akan dilaksanakannya doa padang. Masyarakat desa jaya kopah menyebut daerah tersebut dengan nama Tampang. Disana merupakan tempat yang luas dan cocok untuk menampung masyarakat yang sangat banyak tambahnya. Selain itu, tampang juga memiliki tempat yang strategis yaitu berada ditengah-tengah sawah. ${ }^{11}$

Keempat, Pembawa jambar godang. Dalam rapat yang diadakan akan ditunjuk pula desa yang akan membawa jambar godang. Biasanya dari 6 desa yang ada, masing-masing akan selalu mendapat giliran setiap tahunnya sebagai penyedia atau pembawa jambar godang dari desa mereka untuk dibawa ke acara doa padang.

Kelima, Panitia. Panitia adalah orang atau desa yang ditunjuk untuk mengatur seluruh kegiatan pelakasaan doa padang dimulai dari membersihkan padang, membawa jambar godang, memotong sapi dan memasaknya dan hal-hal lain demi kelancaran pelaksanaan tradisi doa padang. Biasanya yang menjadi panitia adalah desa yang ditunjuk untuk pembawa jambar godang. Dari 6 desa yang ada masing-masing akan mendapatkan giliran sebagai penitia tradisi doa padang.

\footnotetext{
${ }^{9}$ Syamsuar, Ulama, wawancara tanggal 12 Januari 2021

${ }^{10}$ Erman K, Tungganai wawancara tanggal 30 Agustus 2020

${ }^{11}$ Erman K, Tungganai wawancara tanggal 30 Agustus 2020
} 
Petra Yuhendri: Tradisi Doa Padang...

\section{Simbol Tradisi Doa Padang}

Simbol adalah lambang, tanda yang mengandung suatu makna. Makna yang mengungkapkannya adalah mewakili suatu pengertian yang abstrak, luas dan bersifat universal. $^{12}$

Dalam tradisi doa padang ada simbol-simbol yang terlihat ketika dilaksanakannya acara ini yang mana tentu mempunyai tujuan dan makna tersendiri. Syamsuar sebagai tokoh agama memberikan penjelasannya sebagai berikut: Pertama, Tepung tawar merupakan salah satu simbolis dan tangkal untuk melindungi, menjaga, menyuburkan tapak sumanyan (tempat benih padi di tanam) agar terhindar dari musuh atau hama penyakit benih.
Bahan-bahan ini kemudian diikat menjadi satu dan dibawa oleh masing-masing petani pada saat menghadiri tradisi doa padang. Kemudian tepung tawar ini akan diserahkan kepada panitia atau orang yang akan membacakan doa (orang yang didahulukan selangkah oleh para alim ulama). Setelah semuanya terkumpul selanjutnya dilakukan pemotongan ujung daripada daun-daun tadi dan dicampur dengan air dalam sebuah ember besar disertai dengan pembacaan doa khusus kemudian dibagikan kepada para petani.

Tepung tawar ini kemudian akan disiramkan atau ditebarkan disemua area sawah baik untuk tempat menanam benih maupun untuk menanam padi. Sebaiknya air yang digunakan tersebut disiramkan ke semua area sawah tanpa ada sisa. Tepung tawar yang masih diikat akan dikubur atau ditanam ditengah-tengah sawah. ${ }^{13}$

\section{Gambar I}

Tepung Tawar

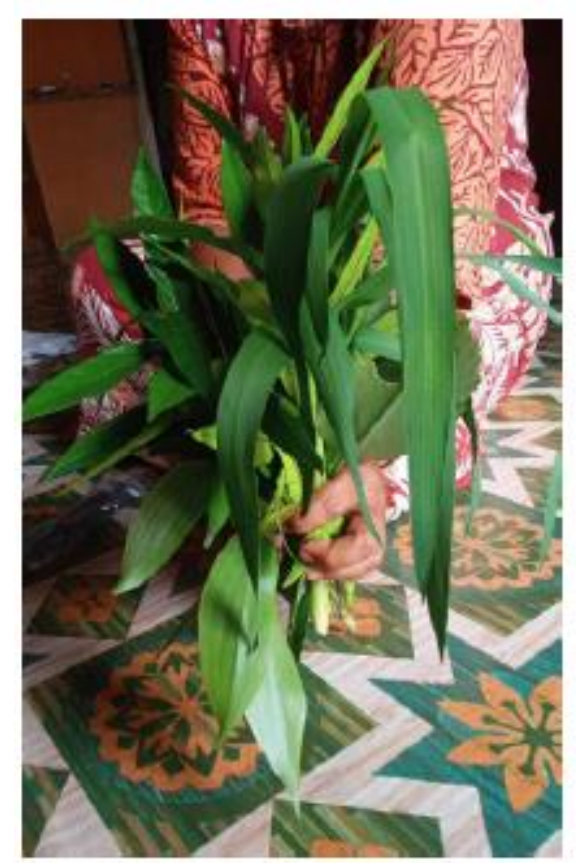

Selama ini tangkal diyakini dapat memberikan kesuburan, kedinginan tanah, menjauhi dari hamahama penyakit merupakan konsep utama dari tepung tawar yang diberikan. Harapan masyarakat dengan pemberian tepung tawar ini benih-benih

${ }^{12}$ Suparlan, Parsuadi, Kebudayan, Masyarakat dan Agama: Agama Sebagai Sasaran Penelitian Antropologi, (Jakarta: DEPAG RI,1981), hlm. 6 padi dan sawah yang ditanam nantinya mendapatkan hasil sesuai yang diharapkan.

Kedua, Pemotongan Saparompek Jawui (Seperempat Sapi). Pada pagi hari para pemuka adat dan alim ulama akan melakukan pemotongan

13 Yusmanidar, Masyarakat, wawancara tanggal 01 Januari 2021 


\section{NUSANTARA; Journal for Southeast Asian Islamic Studies}

Vol. 16, No. 2, Desember 2020

sapi. Pemotongan ini bermakna untuk menjadi tanda kaul atau pengorbanan serta syukur yang ditujukan kepada sang pencipta yang memberi rezeki dan keselamatan tahun.

Dahulu, daging sapi ini akan di rangkai/susun pada lidi daun kelapa sekitar 3 atau 4 potong yang berukuran sebesar jempol kaki orang dewasa. Kemudian dibagikan kepada seluruh masyarakat. Seiring berjalannya waktu pemotongan daging sapi dan proses masak-memasaknya sudah dilakukan oleh panitia pelaksana sehingga tidak ada lagi pembagian daging mentah. Daging yang sudah dimasak akan dibagikan pada saat masyarakat sudah berkumpul di padang.

Perlu digaris bawahi bahwa pemotongan sapi ini semata-mata tertuju dan diniatkan atas nama Allah SWT sebagai kaul masyarakat desa jaya kopah. Selain itu, daging ini juga bertujuan untuk memberikan bantuan kepada para petani yang mungkin tidak memiliki bahan lauk pauk dirumah mereka untuk dibawah pada saat menghadiri tradisi doa padang. Tentu hal semacam ini sangat membantu dan menghindari ketidakmauan masyarakat untuk hadir hanya karena tidak memiliki lauk pauk dirumah.

Ketiga, Jambar godang. Jambar godang merupakan sebuah keranda besar berbentuk rumah gadang yang diisi dengan rangkaian makanan-makanan khas Desa Jaya Kopah yang bahan-bahannya terbuat dari beras (padi) hasil panen sebelumnya yang makanan ini akan disusun/rangkai pada lidi daun kelapa dan digantungkan dikeranda tersebut.

Dari zaman orang tua dahulu jambar godang wajib di buat. Jambar godang menandakan keberhasilan masyarakat dalam bertani pada tahun yang lalu di ungkapkan dengan merangkai atau menggantungkan makanan khas yang berbahan dasar beras yang kemudian akan di bagikan atau disantap bersama.

Jambar godang akan dirarak diiringi pukulan calempong yang onam, gendang kulit dan ogung dari desa menuju tempat pelaksanaan (tampang). Hal semacam ini bertujuan agar terjalinnya kerja sama antara sesama masyarakat desa serta untuk menimbulkan rasa tanggung jawab dan berbagi dengan masyarakat desa lainnya. Selain itu,

\footnotetext{
${ }^{14}$ Syamsuar, Ulama, wawancara tanggal 12 Januari 2021
}

masyarakat lain juga diharuskan membawa lauk pauk dan juga makanan khas tersebut dari rumah mereka masing-masing dalam bentuk kecil saja untuk dimakan bersama-sama. ${ }^{14}$

\section{Pelaksanaan Doa Padang}

Melihat dari singkatnya waktu pelaksanaan yaitu setelah sholat asar sampai menjelang magrib maka tidak banyak pula rangkaian kegiatan yang akan dilaksanakan. Berikut rangkaian kegiatan dalam tradisi doa padang:

Pertama, Rarak. Rarak terdiri dari 6 buah celempong, 1 buah gendang kulit dan ogung yang dimainkan 3 atau 4 orang untuk mengiringi jambar godang. Rarak ini disebut juga dengan rarak calempong onam. Kegiatan doa padang sebenarnya sudah dimulai semenjak diraraknya jambar godang oleh masyarakat (desa sebagai panitia), para ninik mamak dan alim ulama yang diiringi calempong yang onam, gendang kulit dan ogung dari desa menuju ke tampang. Rarak akan berakhir setelah ninik mamak, para perangkat desa dan alim ulama sudah mengambil tempat duduk masing-masing.

Kedua, Sambutan oleh Kepala Desa dan Ninik Mamak. Sambutan yang disampaikan oleh kepala desa biasanya berupa ucapan rasa syukur kepada Allah SWT dan arahan untuk masyarakat agar selalu menjaga kekompakan dan kerja sama baik sesama masyarakat, pemuka adat, agama maupun unsur pemerintahan sehingga tradisi-tradisi yang ada masih terjaga dengan baik, terutama doa padang sebelum memulai bercocok tanam di sawah ini. Selain itu, kepala desa juga akan menghimbau masyarakat agar mengelola usaha taninya sesuai dengan petunjuk oleh para penyuluh pertanian, mulai dari mengelola benih unggul, pengolahan tanah, penggunaan pupuk yang berimbang, pemberian racun dan pengendalian hama dan penyakit. ${ }^{15}$

Ketiga, Arahan dari Pemerintah atau Dinas Pertanian. Beberapa tahun terakhir tradisi dao padang dihadiri oleh para pemerintah Kabupaten Kuantan Singingi, seperti bupati atau camat yang

15 Matnur, Kepala Desa Jaya, wawancara tanggal 01 Desember 2020 
biasanya mereka juga akan memberikan sepatah kata untuk masyarakat dalam acara tersebut.

Keempat, Zikir dan Doa Saropal Onam. Acara inti dari pada doa padang adalah pembacaan zikir yang disebut juga Dikiar dan doa saropal onam (sholawatan). Dikiar merupakan kalimat-kalimat pujian kepada Allah SWT dan kepada Nabi SAW. Dalam proses pelaksanaannya dikiar akan dipimpin oleh orang yang didahulukan selangkah dimasyarakat oleh para alim ulama dan para ninik mamak. Disamping itu, pembacaan dikiar tersebut akan diiringi dengan pukulan barabano (gendang kulit dan ogung tanpa calempong) oleh para kelompok zikir. Masyarakat diharapkan ikut serta melantunkan kalimat-kalimat pujian tesebut.

Setelah agenda pembacaan zikir berakhir acara doa padang akan ditutup dengan doa. Doa dipanjatkan kepada Allah SWT agar diberikan keselamatan tahun, hasil panen yang berlimpah dan terhindar dari segala macam musibah seperti banjir, hama dan lainnya. Doa khusus yang dibacakan disebut Doa Saropal Onam.

\section{Urgensi Doa Padang bagi Masyarakat Desa Jaya Kopah}

Pertama, Sebagai Pewarisan Tradisi. Masyarakat desa jaya amat kaya dengan tradisitradisi ataupun upacara-upacara adat yang masih tetap dipertahankan dan diwariskan secara turun temurun, seperti tradisi pacu jalur, tradisi doa padang, tradisi ziarah kubur, tradisi sepak rago tinggi, zikir berjalan dan lain sebagainya. Tradisitradisi tersebut dilaksanakan oleh masyarakat setiap tahun atau pada musim dan waktu-waktu tertentu saja. Keadaan semacam ini tidak terlepas dari dorongan para tetua-tetua suku maupun para alim ulama untuk senantiasa menjaga dan mempertahankannya meskipun terkadang dalam tradisi-tradisi tersebut banyak hal-hal yang berbau mistik bahkan tidak sesuai dengan ajaran agama yang dianut oleh masyarakat Desa Jaya Kopah.

Kedua, sebagai Keselamatan Tahun. Menurut Uwan Madrasa, pelaksanaan tradisi doa padang pada hakikatnya adalah memohon dan meminta

16 Uwan Madrasa, Ninik Mamak, tanggal 12 Januari 2021

17 Anad, Ninik Mamak, wawancara tanggal 01 Desember 2020 kepada yang maha kuasa, yang maha pemberi rezeki agar diberikan keselamatan tahun bercocok tanam hingga mendapatkan hasil yang berlimpah. Dengan demikian sejahteralah kehidupan masyarakat petani dari tahun ke tahun. ${ }^{16}$

Anad menambahkan pelaksanaan doa padang ini menjadi penting karena acara tersebut menolak segala bencana terhadap padi masyarakat seperti banjir, hama penyakit dan juga padi tidak berbuah. ${ }^{17}$

Sabar mengatakan makanan yang dibawah masyarakat pada saat doa padang yang mana bahan-bahannya berasal dari beras merupakan wujud syukur dan terima kasih kepada Allah SWT, sehingga hasil panen tersebut dapat dimanfaatkan sebaik-baiknya dan dinikmati pula oleh masyarakat lainnya. Selain itu, makanan yang dibawa menandakan bahwa hasil panen tahun sebelumnya telah berhasil dan dipergunakan sebaik-baiknya. ${ }^{18}$

Keselamatan tahun yang dimaksud dari doa padang ini adalah segala kebaikan terhadap padi masyarakat seperti hasil yang melimpah, kesuburan padi, berbuah lebat, terhindar dari bencana alam, dan hama menyakit. Harapan kedepannya adalah semoga yang maha pencipta senantiasa memberikan kemudahan dalam segala kegiatan dalam bercocok tanam setiap tahunnya.

Ketiga, Perlindungan dan menolak bencana. Yusmanidar mengatakan tradisi doa padang memiliki keistimewaan tersendiri. Keistimewaan yang dimaksud adalah adanya kenyamanan dan ketenangan bagi masyarakat setelah pelaksanaannya dibandingkan dengan tidak ada pelaksaannya. Setelah pelaksanaan doa padang masyarakat merasa lebih aman dan percaya bahwa prosesi bercocok tanam hingga masa panen akan dilindungi dan dijaga oleh Allah SWT'. ${ }^{19}$

Agusman $\mathrm{K}$ mengatakan perlindungan yang didapatkan dari tradisi doa padang ini seperti tidak mudah terkena penyakit, bencana alam seperti kemarau atau musim hujan yang berkepanjangan yang menyebabkan rusaknya batang padi sampai gagal panen. Selain itu, penggunaan tepungb tawar yang disediakan adalah sebagai tangkal bagi padi

\footnotetext{
${ }^{18}$ Sabar, Ninik Mamak, wawancara tanggal 19 Januari 2021

19 Yusmanidar, Masyarakat, wawancara tanggal 01 Januari 2021
} 


\section{NUSANTARA; Journal for Southeast Asian Islamic Studies}

Vol. 16, No. 2, Desember 2020

agar dapat menolak atau membentengi padi dari musuh-musuh yang ada di alam. ${ }^{20}$

Keempat, Membangun solidaritas sosial masyarakat. Pelaksanaan tradisi doa padang memerlukan dukungan dan keterlibatan seluruh anggota masyarakat khususnya para petani. Kegiatan yang dilaksanakan setiap tahun menunjukkan bentuk solidaritas sosial di kalangan masyarakat desa jaya kopah. Lebih jauh lagi pelaksanaannya mengajarkan betapa pentingnya melahirkan rasa kebersamaan, senasib sepenanggungan dalam mencapai kemapanan hidup.

Mengingat kegiatan ini memang tidak bisa dilaksanakan oleh sekelompok orang saja karena memerlukan banyak tenaga manusia dan berbagai keahlian agar tujuan yang diharapkan dapat tercapai, maka disinilah akan timbul saling membantu, bahu membahu, ikhlas dan menghargai dalam setiap pendapat. Warga yang memiliki kelebihan harta dapat memberikan bantuan berupa sumbangan dana sesuai dengan kemampuan mereka yang tentu dapat pula meringankan warga lain.

Yusmanidar mengatakan,dahulu sapi yang disembelih merupakan hasil iuran masyarakat yang mana iuran ini tidak memiliki patokan atau menyumbang secara suka rela. Seminggu atau beberapa hari sebelum tradisi di mulai setiap dusun atau desa akan didatangi rumahnya masing-masing guna mengutip atau mengumpulkan sumbangan yang akan digunakan untuk membeli sapi. Biasanya dana yang dikumpulkan dari masyarakat tidak cukup, selebihnya akan ditambah oleh para perangkat desa atau orang-orang dibagian pemerintahan. Selain itu, pembagian daging sapi kepada seluruh masyarakat desa jaya kopah menjadi salah satu bentuk kebersamaan dan saling berbagi antar masyarakat. Menimbulkan rasa kepedulian dan tolong menolong kepada orangorang yang kekurangan bahan pokok atau tidak memiliki bahan makanan untuk dibawa pada saat acara doa padang.

\section{Kesimpulan}

Berdasarkan hasil penelitian tentang Tradisi Doa Padang pada masyarakat Desa Jaya Kopah Kecamatan Kuanatan Tengah Kabupaten Kuantan Singingi, maka dapat diterik kesimpulan; bahwa secara umum masyarakat Desa Jaya Kopah telah mempercayai bahwa tradisi doa padang yang dilakukan mampu memberikan keselamatan tahun (tanah menjadi subur, terhindar dari bencana alam, hama penyakit dan dapat memberikan hasil panen yang berlimpah). Sehingga dengan demikian dapat mendorong masyarakat untuk mengadakan doa padang setiap tahunnya. Susunan acara pelaksanaannya yaitu: sambutan dari kepala desa, ninik mamak dan dinas pertanian kemudian ditutup dengan zikir dan doa saropal onam.

Adapun faktor lain yang membuat masyarakat desa Jaya Kopah tetap mempertahankan tradisi doa padang adalah dianggap sebagai tradisi warisan nenek moyang mereka yang harus dipertahankan disisi lain juga dapat mempererat hubungan tali silaturrahmi antar masyarakat di desa Jaya Kopah umumnya Kenegerian Kopah Kecamatan Kuantan Tengah Kabupaten Kuantan Singingi..

${ }^{20}$ Erman K, Tungganai, wawancara tanggal 30 Agustus 2020 
Petra Yuhendri: Tradisi Doa Padang...

\section{DAFTAR PUSTAKA}

Ali, Mukti. 1969. Alam Pikiran Modern di Indonesia. Yogyakarta: Yayasan nida

Dudiarto Eko dan Dewi Anggraini. 2003. Pengantar Epistimologi. Jakarta: Buku Kedokteran EGC.

Hamidy, UU. 1993 Nilai-Nilai Suatu Kajian Awal. Pekanbaru: UI Perss

Moleong, Lexy J. 2000. Metode Penelitian Kualitatif dan Kuantitatif,. Bandung: Remaja Rosdakarya.

Silawati dan Aslati. 2014. "Menguak Nilai-Nilai Magis Pada Tradisi Pacu Jalur Di Kabupaten Kuantang Singingi",No 2. Pekanbaru: Universitas Islam Negeri Sultan Syarif Kasim Riau

Sugiono. 2009. Memahami Penelitian Kuantitati, Bandung: Alfabeta

Sugiono. 2012. Metode Penelitian Administrasi. Bandung: Alfabeta

Sukardi. 2004. Metodologi Peneitian Pendidikan. Jakarta: Bumi Aksara.

Suparlan, Parsuadi. 1981. Kebudayan, Masyarakat dan Agama: Agama Sebagai Sasaran Penelitian Antropologi, Jakarta: DEPAG RI

Syaltut Mahmud, 2006. Fatwa-Fatwa Penting Syaikh Shaltut, (Dalam Hal Aqidah Perkara Gaib dan Bid'ab). Jakarta: Darus Sunnah Press. 